\title{
Geopolitics of International Relations, Ethnic Polarization and Internal Conflict
}

\author{
https://doi.org/10.21272/sec.3(4).25-38.2019
}

Saima Toqueer, ORCID: https://orcid.org/0000-0001-7239-6903

MSc, Consultant and Freelance Researcher, Olso, Norway

\begin{abstract}
Geostrategic position of a country not just creates opportunities in form of bilateral and multilateral collaborations, it may also pose stern long term concerns and spillover effects in terms of insecurity and conflict. Pakistan, if not a classic example, is a typical case of continually high geopolitics of international relations: its geostrategic location had been praised by international players during the cold war regime through financial assistance; it was encouraged to take part during the Russian invasion in Afghanistan in late 70's; and was compelled to play the role of 'front line state' in the war against terrorism, in the aftermath of the 9/ 11 incidence, in 2001. Early attempts of establishing rebel groups based upon ethnic identity to fight in Afghanistan, while launching of ruthless military operations after 9/11 incidence, against same rebel groups who fought in Afghanistan during the Russian invasion, causing either undue leverage to specific ethnic minorities at one point in time or extreme repression at later stage of history. In order to pretest impact of geopolitics of International Relations upon conflict, and if the interplay of geopolitics with 'ethnic polarization' affected 'internal conflict', several econometric models have been estimated. Along with testing the impact of geopolitical importance and its interplay with ethnic polarization in distressing peace, other important propositions in estimated models include, how 'external conflict', 'institutional efficacies', and the 'role of military in politics', caused adversity of 'Internal conflict', in Pakistan. In order to ensure concurrent validity of econometric models, alternative regressands namely ratings of 'Civil War' and 'Internal Conflict' have been used. Keeping in view ordinal scaling of regressands, cautions in dealing with heteroscedasticity and potentially lagged impact of regressors, Ordered-probit, Ordered Logit, Quantile regression, Robust Regression, and Prais-Winsten models are estimated. Estimated models strongly approved the notion that 'geopolitics of international relations' and 'geopolitics of International Relations' in interaction with 'Ethnic polarization', have had a considerable and statistically significant temporal impact upon 'internal conflict' and rating of 'civil war', in context of Pakistan. Other significant factors that contributed to adversity of peace are 'external conflict', 'role of military in politics', 'illegitimacy of the state actions'/ 'institutional inefficacies' and 'religious polarization'.
\end{abstract}

Keywords: geopolitics of international relations, war against terrorism, internal conflict, ethnic polarization, ordered-probit model, robust regression, Prais-Winsten regression.

JEL Classification: C32, C35, D74, F51, F52, Q34.

Cite as: Saima, T. (2019). Geopolitics of International Relations, Ethnic Polarization and Internal Conflict: A Case for Pakistan. SocioEconomic Challenges, 3(4), 25-38. https://doi.org/10.21272/sec.3(4).25-38.2019.

(C) The Authors, 2019. This article is published with open access at Sumy State University.

\section{Introduction}

Livelihood, peace and endurance of many countries in the world pretenses to fragility and risk due to one or the other dimension of geopolitics (Braithwaite \& D'Costa, 2018; Flint, 2017; Reuber, 2009): countries like Iraq and Syria have been facing guerilla warfare and stringent military operations by coalition led forces, due to geopolitics of oil (Flint, 2017; Quy-Toan et al., 2018); North Korea and Iran were pushed to wall through sanctions due to geopolitics of nuclear capabilities (Wallace, 2014; Dudlák, 2018); China and Laos, Turkey and many others are in a conflict like situation due to resource endowment or the geopolitics of fresh water; while some countries paid high opportunity cost and negative spillovers due to their geostrategic location and the resulting geopolitics of international relations, such as Pakistan (Nasir, Rehman,\& Orakzai, 2012; Flint, 2017; Braithwaite \& D'Costa, 2018).

Data on conflict and security reveals that before commencement of the geopolitical characteristic, the peace and security rating of all above mentioned countries was favorable to a large extent, than their rating and ranking regarding conflict after being exposed to high geopolitical significance. For instance, Series of UN Security Council resolutions were passed from 2006 to 2017 in response to North Korean nuclear capabilities and to exert pressure sanctions and embargos were imposed, leading to vulnerabilities for North Korea: the International Country Risk 
Guide (ICRG) data for North Korea on 'External Conflict' (Scale 0-12: 0 for extreme international pressures, while 12 for no external intervention), which ranged around 9.5 in 2000, deteriorated to 5.5 in 2011. Moreover, the ICRG 'Internal Conflict' rating (Scale 0-12: 0 for High conflict, while 12 for no conflict) of North Korea which was at a sustained rating/ level of 12 in 90's, dropped to 9 since 2008. Perhaps, North Korea survived the external pressures and its economy didn't collapsed due to the reason that there is very low ethnic segregation in North Korea: ICRG 'Ethnic Tensions' rating (Scale 0-6: 0 for High ethnic polarization, while 6 for Low ethnic polarization), which ranged at 6 in mid 90's, sustained at 6 till 2018. Regardless of all good reasons of endurance, North Korea witnessed growth recession from 2012-14 and then years of recession from 2015 onwards, as its 'Investment Profile' rating (Scale 0-12: 0 for in conducive, while 12 for conducive) which ranged around 7 or more in 2000, deteriorated to level of 4, since 2010. In context of Iraq, UNDP suggested that the HDI (Human Development Index) ranking which ranged $55^{\text {th }}$ in 1990 , dropped to 120 in 2019. Correspondingly, stringent sanctions were imposed on Iran in 2006 and onwards to restrict its nuclear capabilities. As an outcome of immense foreign pressures, the ICRG 'External Conflict' rating for Iran, which ranged around 8.5 in 2003, deteriorated to 5.5 in 2012. ICRG 'Ethnic Tensions' rating of Iran which ranged around 5 in 2000 and deteriorated to 3.5 since 2012, as US start promoting Kurdish and Khabat rebel groups. Similar state of affairs have been observed in case of Syria since 2014: the US led coalition forces tried to topple the political regime of Bashar al-Assad through fatal airstrikes and by supporting rebel groups, while counter attacks on rebel groups by Assad regime caused severe humanitarian crisis. 'External Conflict' rating of Syria which ranged at the level of 10 in 2000, dropped to below 6, since 2014 implying sizable international pressures. Proliferation and polarization as caused by international players through militarization of ethnic based rebel groups in Syria implied 'Ethnic Tensions' to deteriorate: form a well thought-of rating of 6 in late 90's to early 2000 to the level of 2.5 , after 2014.

Pakistan is a bit a distinct case among other countries with multifaceted geopolitical significance. It is tied on territorial disputes with India on Kashmir issue (Makeig, 1987; Flint, 2017), tied on the basis of geopolitics of fresh water with India on matters of compliance with the Indus Basin treaty (Wolf et. al, 2005; Uprety \& Salman, 2011), faced international pressures and sanctions due to geopolitics of nuclear capabilities (Geller, 2003), and always inclined to be a willing follower of US at times of conflict in the region due to its geo-strategic positioning (Fleck \& Kilby, 2009; Meernik, Krueger \& Poe, 1998).

Referring to post cold war management of international affairs, Modelski (1987) observed that US is inclined to be a "leader" of willing followers and the NATO, instead of its solitary status as hegemonic superpower. During Cold War regime, Pakistan was considered by US as a potential ally to curtail Russia and to keep an eye on it. In order to buy support and collaboration from Pakistan, US extended economic assistance, primarily in the form of grant component of Foreign Aid, since 1949. This mega plan of extending economic assistance to some of the countries meant to praise their geo-strategic positioning (Meernik, Krueger \& Poe, 1998). From initiation of the financial assistance by the US in late 40's, Pakistan starts receiving US bilateral Economic assistance, since 1949. Initially foreign aid inflows were in form of economic assistance, while during periods of Russian invasion in Afghanistan from 1979 to 1990 and then again after the 9/11 incidence, from 2001 to 2011, Pakistan also received US military assistance as well as the coalition support (Pakistan Bureau of Statistics, 2019). The grant component of Foreign Aid, which ranged around $80 \%$ of all Aid inflow in 50's, declined gradually, implying permanent financial dependencies Pakistan over international players, with added vulnerabilities of Pakistan to exercise sovereignty in dealing with matters of Foreign policy (Fielden, 1998). To transmit sovereignty of the state of Pakistan into vulnerabilities and low bargaining potential against international players, tactical tools such as tied loans, IMF aid conditionalities, halting IMF seal of approval to induce collaboration, and signaling through threat of sanctions, were used continually and consistently (Nasir, Rehman,\& Orakzai, 2012). To the extent that Foreign aid which Pakistan received during worst disasters such as major earthquake in 2005, and then heavy floods during 2012, under the title of Humanitarian Aid, predominantly was in form of loans instead of grants.

\section{Foreign pressures, Polarization and Conflict ratings of Pakistan}

For quite some time, most of peace and security ratings and forecasts for Pakistan e.g. by the 'Fund for Peace', 'International Country Risk Guide' and by the 'Economist Intelligence Unit', show a bleak situation. Overall 'State Fragility' rating according to Fund for Peace for Pakistan is 9.6 in 2018 (Scale 0-10: 10 imply worst vulnerability/ fragility). Indicators of class conflict such as 'Group Grievances' rating was estimated at 9.7 in 2018 (Fund for Peace, 2018); implying sizeable polarization, lack of harmony and creeping conflict. As an outcome the 'Security Apparatus' rating was 8.8 in 2018. Rating of Pakistan with regard to Refugees and IDP's pressure was at 8.4 in 2018, implying low to moderate absorption capacity of the state in dealing with displacement that may be due to disasters or due to military operations (Fund for Peace, 2018). Figure1 below depicts frequency or positioning of 
ICRG 'Civil war' rating (scale 0-4: 0 being very high risk of civil war, while 4 imply low risk of civil war. The data has been interpolated till 2001), for Pakistan for the duration 1984 to 2016, International Country Risk Guide (ICRG) data by the Political Risk Services Group (PRS Group).

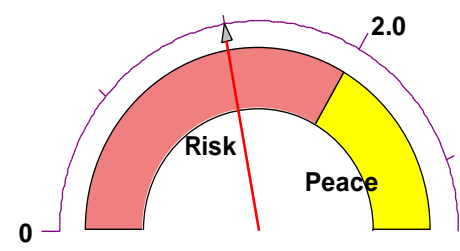

Figure 1. Dashboard gage image of civil war rating (0: high risk)

Source: ICRG Civil War rating for Pakistan based upon 1984 to 2016 data.

The dashboard image in Figure 1, depicts that for almost two third of the duration, the 'Civil War' rating of Pakistan ranged below 2, implies severely adverse rating or the high risk of 'civil war'. Another measure that quantifies the degree of tensions, grievances and conflict like situation is the ICRG data on 'internal conflict'. Figure 2 below, shows frequency or positioning of ICRG 'internal conflict' rating (scale 0-12: 0 being very high risk of 'internal conflict', while 12 imply low risk of 'internal conflict'), for Pakistan for the duration 1984 to 2016.

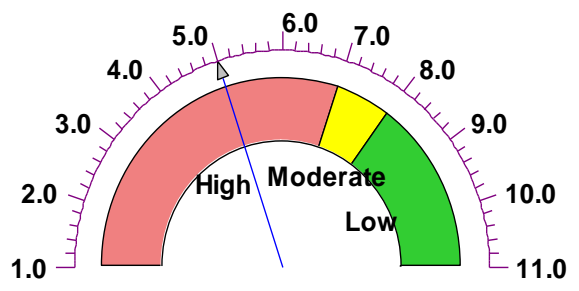

Figure 2. Dashboard gage image of internal conflict (low estimate imply high risk)

Source: ICRG Internal Conflict rating for Pakistan based upon 1984 to 2016 data.

Data dipicts that for the duration 1984 to 2016, the average rating of 'internal conflict' for Pakistan was 5 (severe risk), while for over $60 \%$ instances there was a conflict like sitution of severe to high intensity. The figure 3 below, shows a time series transition in rating of 'internal conflict'.

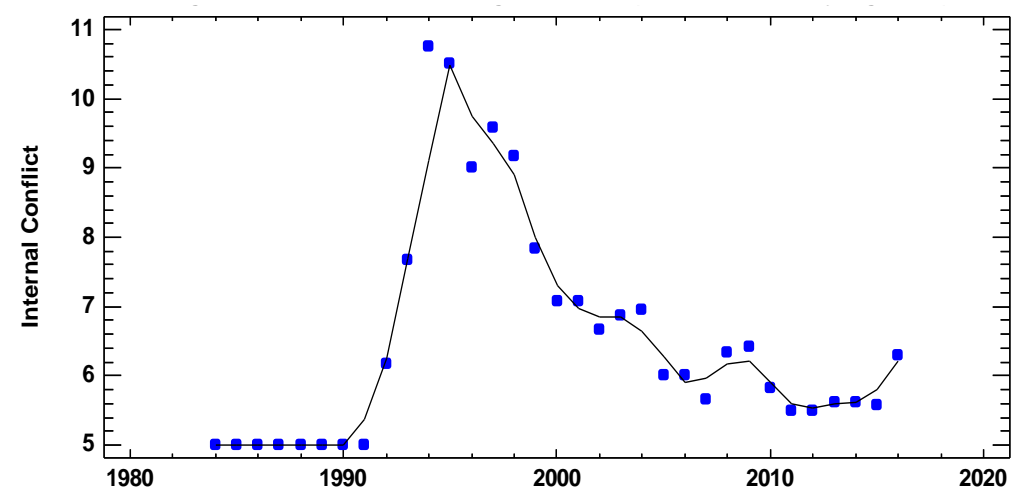

Figure 3. Internal conflict rating on Pakistan (low estimate imply of high risk)

Source: ICRG data on Pakistan 1984-2016.

It is interesting to observe that from 1984 to 2016, for atleast sixteen years (1984-1989 and then 2002-10), Pakistan was either collaborating with US in Afghan War during the Russian invasion or after the 9/11 incidence as a front line state in war against terrorism (Anderson, 2004; Dalby, 2004). The data shows that the 'internal conflict' rating was extremely adverse during the Russian invasion in Afghanistan from 1984 to 1990, it improved substantially after the Afghan War from 1991 to 2000, and then dropped sharply towards adversity after the 9/11 incidence in 2001, as US led coalition forces compelled Pakistan to be a part of 'war against terrorism. Kalyvas and Laia (2010) suggested that the end of cold war has shaped the internal conflicts 
as in post cold war era most of the Irregular wars have transformed into internal conflict. Irregular war is not the classic mode of civil war rather closely associated with the structural characteristics of cold war.

\section{Lead led role of Geopolitics of International Relations in causing Polarization and risk of Conflict.}

Geostrategic location of a country if been exploited and maneuvered at times of international conflicts time to time or consistently, cause a significant lead led role in creeping multifaceted and incremental dimension to risk and insecurity (Flint, 2017; Meernik, Krueger \& Poe, 1998; Reuber, 2009). To ensure active participation of Pakistan in Afghan war that started in 1979, along with direct involvement of security establishment, rebel groups were formed and established on the basis of religiosity or ethnic identity so that mass support or the fuel for war may be generated from relatively deprived regions of Pakistan such as Bajour, Waziristan and Swat districts. Keeping in view the terrain of Afghanistan, guerrilla warfare was supplemented by regular military involvement (Braithwaite \& D'Costa, 2018). After the end of the Afghan war in 1989-90, these militant groups kept on influencing politics and government formation in Afghanistan and in Pakistan as pressure groups and are being termed as 'non state actors'. Rough Terrain in Afghanistan, which is an indicator in Fairon and Laitin (2003) study for accelerating insurgency, was the hindrance in curtailing the counter major power Soviet Union in Afghanistan in 1979 and then Taliban in Afghanistan in post 9/11 scenario, therefore US used the Pakistan and provided them the military advantages and technology. The initiative to buy support from Pakistan, the Military assistance to Pakistan witnessed fluctuations in periods of high geopolitical significance of Pakistan (Nasir, Rehman \& Orakzai, 2012).

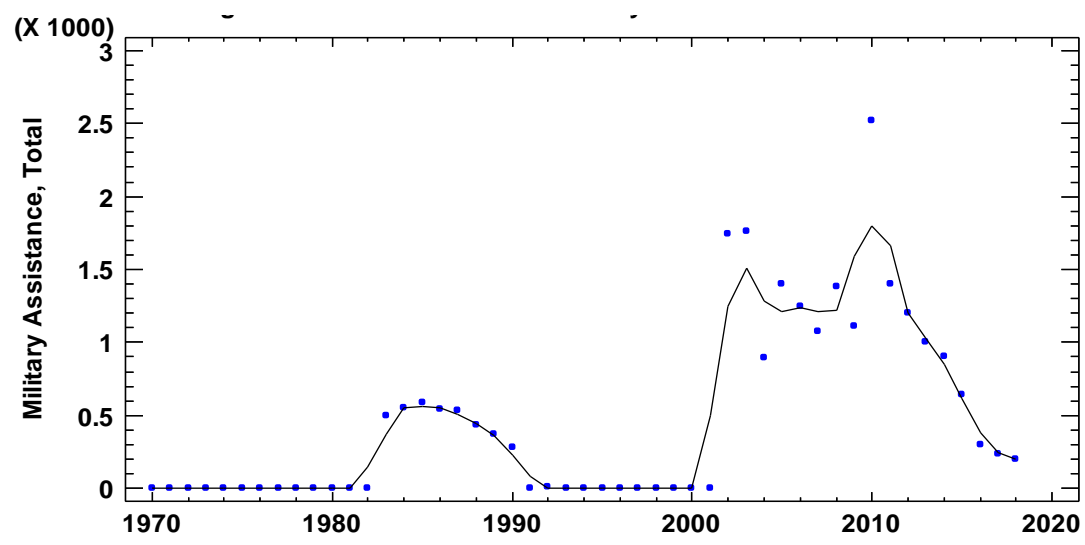

Figure 4. Time series plot of military aid to Pakistan from 1970-2018

Source: Statistical Bureau of Pakistan 2019.

The figure 4 above shows transition in Military Aid to Pakistan by the US, over the duration 1970 to 2018 . Trend shows that the US military assistance to Pakistan increased from 1980 and then dropped to almost 0 at the end of the Russian invasion in Afghanistan. Military Aid increased again just after the 9/11 incidence in 2001, peaked in 2010 and since then there has been a persistent decline (Pakistan Bureau of Statistics, 2019).

Geopolitics of cold war tried to maintain the balance of power internationally, therefore support for other group's rebellion governments or direct involvement, or by using the third state to facilitate them escalate the conflict. It is commonly perceived that the civil wars proliferated soon after the end of the cold war. Current prevalence of internal war is not an outcome of the sudden change linked with post cold war international system, rather its traces can be found from prolonged favor of major powers to the insurgency during 50s to 80s (Fearon \& Laitin, 2003). Fearon and Laitin tend to argue that factors that explained which countries are at the risk of civil war are not the ethnic or religious characteristics, rather conditions that favor insurgencies. These expanded and prolonged favors for insurgencies or support for insurgency can be problematic. While identifying causes of conflict and civil war Collier and Hoeffler (2004), described the Atypical grievances and atypical Opportunities. While taking into account quantitative indicators of opportunity they describe the financing rebellion as an instrument of motivating rebellion and causing conflict (Collier \& Hoeffler, 2004). Keeping in view of the Collier and Hoeffler's opportunity model one can argue that Pakistan was used and financed to motivate the rebellions against Soviet Union in Afghanistan in 1979 and later against Taliban in Post 9/11 Scenario. 
The figure 5 below shows transition in Economic Assistance to Pakistan by the US, over the duration 1970 to 2018. Trend shows that the US military assistance to Pakistan dropped as soon as the Zia ul Haq Martial law was imposed in 1977, showing disliking for a military regime. While in the same regime lead by Zia ul Haq, US Aid inflows increased from 1980 as soon as Russia invaded Afghanistan (Fielden, 1998; Braithwaite \& D'Costa, 2018). As soon as Russia left Afghanistan, the US Aid dropped to almost 0 in 1990-91 till the 9/11 incidence and peaked again in 2010. Since then, inflow of Aid is on decline, endorsing the notion that in periods of high geopolitical significance of Pakistan sizable aid was available, while in case of non compliance with conditions and instructions of international players, such inflows reported a sharp decline (Pakistan Bureau of Statistics, 2019).

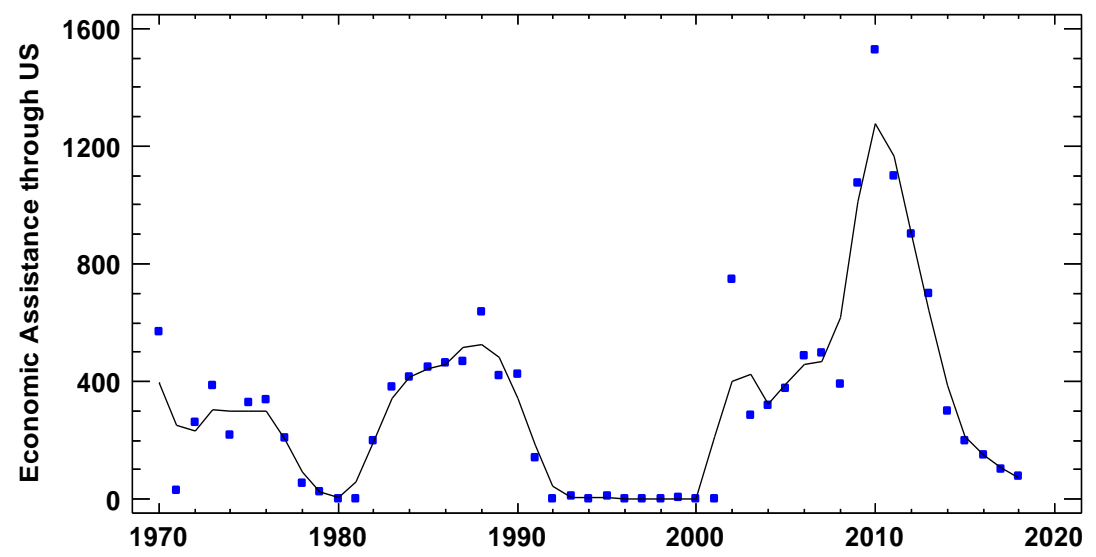

Figure 5. Time series plot of US Bilateral Economic Assistance to Pakistan from 1970-2018

Source: Statistical Bureau of Pakistan 2019.

Keeping in view rational decision of the leadership and state regarding bargaining, cost and risk of conflict may decrease or increase the intensity of conflict (Fearon, 1995). If credibility of the Commitment is in doubt then peace is crucial. The use of Pakistan's strategic territory and making commitments for military advantages and foreign aid appeasements makes the Fearon's model more relevant.

Since 1949, Aid inflows primarily or predominantly were in form of the grant component, which transmitted into debt and then in forms of tied/ conditional debt, over time: causing a sovereign country to appear as a permanent dependent economy, and vulnerable against international players, for livelihood (Fleck \& Kilby, 2009). The right of making public policies in accordance with national interests is either restrained or constrained by such international players: external pressures and compulsion to extend support in a conflict like situation restrain policy options while noncompliance with such pressures may result in sanctions or conditionalities (Nasir, Rehman,\& Orakzai, 2012).

Economic sanctions were imposed on Pakistan in forms of Brown and Pressler amendments, due to its nuclear capabilities, in 1999 (Ali, 2009). Similarly, Pakistan was compelled to extend military support to US and NATO just after 9/ 11 incidence, in 2001 (Reuber, 2009; Nasir, Rehman,\& Orakzai, 2012). As soon as Pakistan extended its military support in preemptive strikes on Afghanistan, not just the US bilateral economic assistance resumed, but the long awaited military support and the coalition support funds were also been resumed. As Pakistan faced huge financial loses as well as the loss of human lives as an outcome of military operations in Afghanistan, the Government of Pakistan led by Pakistan People's Party, released their estimates of damages in this war against terrorism, in 2010. Pakistan claimed that damages in this war against terrorism ranged around \$ 68 billion from 2001 to 2010, while the Aid inflows in duration were only a fraction of it. For instance for the year 2010 damages of war amounted to $\$ 17.83$ billion, in comparison to the amount of foreign aid of only $\$ 3$ billion, which Pakistan received in forms of military assistance and the coalition support fund (Government of Pakistan, 2010). As Pakistan insisted on payment of damages to Pakistan, while the US and coalition forces were demanding 'do more', apparently there was a deadlock situation between the Government of Pakistan and US led coalition. 
Foreign pressures and border tensions have had adverse effect upon extent of 'Internal Conflict'. Figure 6, the component chart below depicts close association between foreign pressures, border tensions and adversity of internal conflict for Pakistan.

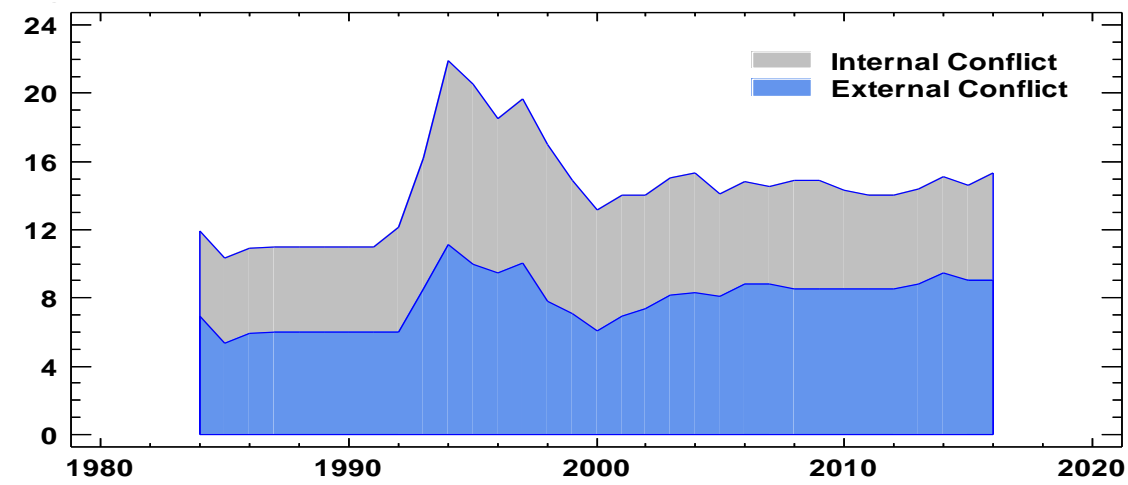

Figure 6. Component chart of interplay between external and internal conflicts

Source: ICRG data on external and internal conflict from 1984 to 2016.

Demands by international players, appearing in form of foreign pressure, if complied or even otherwise, pose risk for domestic security. The figure above shows close collaboration or interplay between risk of 'external conflict' and adversity of 'internal conflict', in Pakistan.

There are several reasons to believe, how foreign pressures and geopolitical significance of a country may cause segregation and polarization in a society, leading to internal conflict and insecurity (Fearon \& David, 2003; Anderson J. 2004; Dalby S. 2004). Despite the fact that ethnic based rebel/ militant groups are sometimes been established or appreciated by the state, they may participate in proxy wars, damaging the nation state. If state functions under influence of such pressure groups, it can't engage all stake holders, causing segregation in society. Militant groups are provided with arms and ammunitions to participate in war like situation and when such groups return their homeland and try to exercise similar tactics of negotiation and bargain, by the use of force it promotes prejudice and hatred in society (Braithwaite \& D'Costa, 2018). One critically treacherous intervention by the US and coalition partners who were regulating the Afghan war was witnessed in 80's when around 13 million copies of violent and radically religious books were distributed not only in Madrassas but in refugee camps as well, so that to creep radicalized mindset and arrange fuel for war (Ollapally, 2008). Later in post 9/11 scenario such radical elements were either eliminated or been factionalized by force: resulting in inland military operations (such as military operations in Swat Bajor and Waziristan agency), or banning of many militant organizations. All such radical initiatives by the state cause high risk of uprising, insurgency or mutiny. Ethnic polarization or exclusion in a society gives rise to grievances which in turn has major consequences for geopolitics (Nasir, Rehman,\& Orakzai, 2012; Flint, 2017; Cederman et. al, 2013). Since India and Pakistan tested nuclear capabilities, theories of conventional balance of power to cause damage or to seek peace have been redundant, while use of nuclear weapons may have mass bilateral devastation effect. In such a complex situation it is more convenient for international players and neighbors to be inclined towards proxy wars, to cause strategic damage to security and integration of Pakistan: infiltration, financial support to rebel groups, providing ammunition to rebel groups and supporting insurgencies are typical tactics that strengthens the association between interventions and ethnic polarization in affecting peace in Pakistan.

The data for Pakistan on interplay between 'ethnic tensions' and 'internal conflict', in figure 7 below depicts closely correlated and associated response of 'ethnic tensions' in relation to overall rating of 'internal conflict'.

In extending human and logistic support to international forces in a conflict like situation, generally remote and deprived areas remain in lime light. Further deprivation in form of loss of property and infrastructure is added into present vulnerabilities. Follow up in the form of rehabilitation remained absent not only due to the reason that governments face financial constraints in post war era but also due to the reason that foreign aid dropped sharply as soon as needs of international players are fulfilled (Nasir, Rehman \& Orakzai, 2012). 


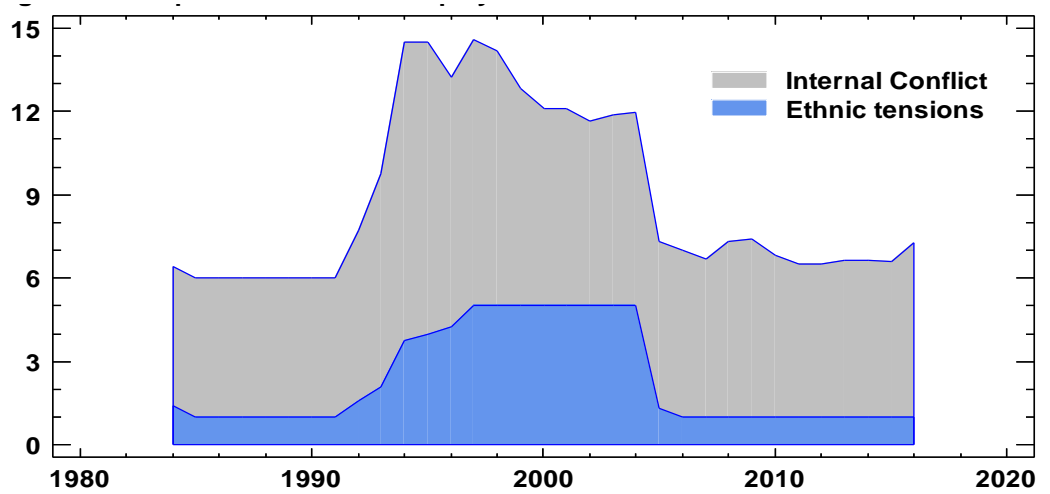

Figure 7. Component chart of interplay between ethnic tensions and internal conflict

Source: ICRG data for Pakistan from 1984 to 2016.

The history of Pakistan with regards to collaboration with international players in conflict like situation has witnessed significant variation and volatility in inflows of foreign assistance (Fleck \& Kilby, 2009; Nasir, Rehman,\& Orakzai, 2012). It is interesting to observe that during and just after wars between India and Pakistan in 1965 and then in 1971, the US military assistance to Pakistan dropped sharply, while the pattern of significant decline may also be seen in US bilateral aid to Pakistan. The US economic assistance to Pakistan that ranged around 600 million dollars in 1976, dropped to 128 million dollars in 1979 as the US disliked imposition of Martial Law by General Zia-ul-Haq in 1977 (Pakistan Bureau of Statistics, 2019).

Political institutions and their role in contributing civil conflicts, in Intermediate regimes are more prone to civil war because the repression and grievances of the people led them to the civil conflicts (Hegre et al., 2001), as repression leads to grievances that induce groups to take action, and openness allows for them to organize and engage in activities against the regime. Such institutional contradictions imply a level of political incoherence, which is linked to civil conflict.

The Inverted U Curve relationship between democracy and conflict signify that strictly authoritarian states and stable democracies experience fewer civil wars than intermediate regimes (Gleditsch \& Ruggeri's, 2010). While applying this model on Pakistan's geopolitical situation and entry of Martial Law's administrator Zia ul Haq, an irregular leader in 1977 increased the conflict like situation. Foreign aid to Pakistan also dropped quickly after the imposition of Zia's martial law. As soon as Russia invaded Afghanistan in December 1979 the same military dictator General Zia-ul-Haq was offered not only of economic assistance but also in the form of military assistance. When the Soviet Union was pulled back from Afghanistan not just the military assistance but the economic assistance also dropped quickly and sharply since 1990 and dropped to only 27 million dollars in 1992 (Pakistan Bureau of Statistics, 2019).

As Pakistan tested its nuclear capabilities in 1999, due to Pressler and Brown amendments which were endorsed by US Congress, sanctions were imposed on Pakistan and the US aid dropped sharply (Ali, 2009). Just after 9/11 incidence the US President George Bush compelled Pakistan to be a Front Line State in preemptions and operations in Afghanistan (Anderson, 2004; Dalby, 2004), the economic assistance by US increase from 0 to 744 million dollars, the military assistance increase to 1739 millions of dollars and the coalition support fund rose from 0 to 1386 millions of dollars in 2002 (Pakistan Bureau of Statistics, 2019).

In recognition of direct damages to military personnel as an outcome of military operations, counter reaction of military operations in form of militancy and suicide bombing in Pakistan, the Government of Pakistan was reluctant to extent further support in collaboration with international Players. In order to be more precise and concrete in damage assessment due to war and terrorism a separate chapter on damage assessment due to the war against terrorism was added in Economic Survey of Pakistan. Chenoweth and Maria (2012) termed the terrorism as an outcome of violent movement and participation in conflict. In order to manipulate the resistance from the Government of Pakistan to 'Do More' in war against terrorism, the 'Kerry-Lugar-Berman Act' also known as 'The Enhanced Partnership with Pakistan Act 2009' amounting to 4.5 billion dollars was initiated and offered to Pakistan in October 2009. Since then there have been complains and demands to 'Do More' by international Players and a persistent attitude of refraining from international conflicts by the 
political leadership of Pakistan, resulting in a continual and persistent decline in US bilateral aid to Pakistan, military assistance and the coalition support fund.

During the time of high need to get support from Pakistan along with inflows of foreign aid, terms and conditions of aid remained lenient, the US influence on International Financial Institutions such as IMF and World Bank facilitated financial outreach to the extent that the Transparency International reported low levels of corruptions in periods of high Geopolitical significance, while adverse rating in periods of sovereign foreign policy. While in periods of refrain from international disputes not only aid inflows were restricted, terms and conditions of foreign aid were harsh, seal of approval by IMF were absent, even institutions such as Transparency International reported a high perception of corruption. The transparency international data on 'perception of corruption'(Scale 0-10, 0 imply high corruption, while 10 imply no corruption), which is widely been used and referred in popular media showed a bleak situation, especially whenever Pakistan exercised its sovereign stance in making of foreign policy or whenever Pakistan resisted to 'do more' in war against terrorism in Afghanistan. For instance, according to 'perception of corruption index' by transparency international, Pakistan was ranked 71 with the score of 2.7, in 1998. As soon as Pakistan retaliated to international pressure to test its nuclear capabilities, in 1999 the corruption perception ranking dropped to 87, with a score of 2.2. Similarly, in 2001 report the transparency international rated Pakistan at the level of 2.3, but as soon as Pakistan decided to collaborate with US to fight its rating improved to 2.6 in 2002. Furthermore, in 2009-10 Pakistan resisted to 'do more' in Afghanistan in anticipation of huge financial losses it faced, resulting in drop of corruption perception rating to 2.3 with the worst ranking of 143 (Transparency International, 1995-2018). High perception of corruption caused several political regimes to appear unpopular or termination of regimes on charges of corruption, in Pakistan. Fake data, misrepresented estimates and media trials on the basis of such weak quality data leave legacy in form of either mistrust or distrust on elected political regimes. Unfortunately, the price of the doubt as arising in form of perceived corruption in political setup is either to be paid by politicians or is an inducement for establishment to impose martial law. It is interesting to mention that the transparency international data is also been referred into several databases of the W orld Bank, such as the 'World Development Indicators' and 'Doing Business'. Unlike the misperception been created by transparency international against sovereign regimes, the ICRG data on corruption in Pakistan (Scale 0-6: 0 imply high, while 6 imply no corruption) depicts that during periods of cooperation with US in Afghan war the rating remained at the level of either 1 or 2, improved to 2 up to the level of 3 during 1992-2009 (post conflict regime), but deteriorated again to the level of 2 and then to 1.5 after the 9/11 incidence, when Pakistan participated in war against terrorism in Afghanistan. Fact of the matter is that the ICRG data due to its extraordinary high price, is used either by top multinational corporation for risk assessment or by academicians for making critical inference, but is not available freely for public consumption, so misperceptions about transparency of a regime is easily been manipulated by the transparency international data.

Culmination and curbing militant groups started, especially after the $9 / 11$ incidence. Military operations, induced vulnerabilities of military operations and the aftermath transmitted apparently a peaceful society towards polarization, high internal insecurity and higher degrees of conflict (Nasir, Rehman \& Orakzai, 2012).

Accountability of government officials including all tears and politicians as well is always seen as correction mechanism to ensure transparency and to avoid misuse of public office in forms of petty corruption, middling corruption as well as grand corruption, in the public sector. The National Accountability Bureau (NAB) who looks into matters of corruption in the public sector state institutions, virtually focuses on politicians alone as they are seen as easy prey. Several political regimes in last three decades or more such as led by Benazir Bhutto, Nawaz Sharif, Yousaf Raza Gilani and by Asif Ali Zardari were either terminated on charges of corruption or forced to leave as an outcome of the propaganda in form of media/ judicial trials, with a conviction rate of almost zero. It is generally believed that establishment manipulates NAB and other institutions that are responsible for justice, for political maneuvering and to victimize political opponents. Asif Ali Zardari, ex President of Pakistan was imprisoned for 11 years on several charges of corruption, with conviction in not a single case. Institutions of justice remain unable to recognize the opportunity cost which is being paid by political prisoners during trials in form of maltreatment, ruthless torture and abuse and later consequences which such politicians have to bare in their span of life in terms of bad repute. Recently, ex Prime Minister of Pakistan Nawaz Sharif and the ex President of Pakistan Asif Ali Zardari both were in the 
physical custody of NAB, on further charges of corruption. Because of maltreatment of both politicians in interrogation process, currently both are facing life threatening condition, but the justice system remained calm. The World Justice project analyzes efficacy of justice based upon diverse parameters: ability of the justice system to ensure 'fundamental rights'; role of the justice system in ensuring 'order and security'; 'corruption in judiciary'; 'improper influence of public officials on judiciary'; quality of 'civil justice'; quality of 'criminal justice' system; access to justice; and on the basis of efficacy of 'regulatory enforcement'. World Justice Project 2019 ranked Pakistan at 117 out of 126 surveyed countries; 2017-18 report by WJP ranked Pakistan at 105 out of 111 surveyed countries; 2016 report ranked at 106 out of 113 surveyed counties; while according to 2015 World Justice Project report Pakistan ranked 98 out of 102 surveyed counties (Adams et al. and The World Justice Project, 2019). Low qualities of justice, especially for politicians, incline them to seek out agitational or the politics of resentment: so that losses as caused by vindicated behavior of institutions/ establishment may be minimized. We believe that the quality of the justice that is being provided to politicians in Pakistan, necessitate separate in depth analysis.

\section{Methodology, Model Estimates and Analysis of Findings}

Out of several possible theoretical explanations or causative factors that may increase or curb conflict or insecurity, it is important to identify which few factors contributed predominantly in context of Pakistan, in a time series setting. The literature on the subject shows diversity from subjective to objective methods for making such inference. Time series regression models have been reported widely to identify factors that regulate conflict/insecurity. The first preference in estimating time series regression is to get consistent time series data on regressand and regressors. Several databases have been consulted for that matter such as the Fund for Peace, Economist Intelligence Risk ratings, Freedom House etc. and eventually the International Country Risk Guide (ICRG) data by the Political Risk Services Group (PRS Group) has been preferred due to its consistent coverage, since1984. Regression models are estimated taking the data for 33 years, so that apprehensions of 'chance correlation' may well be avoided. For quantification of alternative regressands, ICRG 'Civil War' rating and 'Internal Conflict' ratings are used. ICRG methodology suggests that 'civil war' ratings ranged from 0-4: 0 imply high probability of Civil War, while 4 imply virtually no probability of Civil war. The data on civil war has been interpolated till 2001. While, the 'internal conflict' rating is estimated on a Scale 0-12: 0 imply High conflict, while 12 suggest no conflict.

Regessors in competing models include: Rate of Unemployment (IMF Data); Litigation against State Institutions (Petitions against State Institutions at Federal Ombudsman); ICRG data on 'External Conflict' (Scale 0-12: 0 imply extreme international pressures, while 12 imply no intervention); ICRG data on 'Military in Politics' (Scale 0-6: 0 means significant intervention, while 6 refers to no intervention); ICRG data on 'Ethnic Tensions' (Scale 0-6: 0 for High Tensions, while 6 imply Low Tensions); Dummy for Low/High Geopolitics of International Relations (1: high significance, 0 neutral), variable has been assigned value of 1 from 1984 -1989 and from 2001 up till 2011; Interaction 'Dummy for Geopolitics of International Relations' with 'Ethnic Tensions'; ICRG data on 'Democratic Accountability' (Scale 0-6: 0 for no accountability, while 6 means highly accountable); ICRG data on 'Religious Tensions' (Scale 0-6: 0 for High Religious Tensions, while 6 for Low Tensions); and the ICRG data on 'Government Stability' (Scale 0-12: 0 for instability, while 12 for highly stable).

In order to strive for 'concurrent validity' of regression models, alternative regressands have been used namely 'civil war' rating and the 'internal conflict' rating. Taking civil war as regressand three models namely Robust Regression, Ordered-Logistic model and Prais-Winsten Regression have been estimated; while taking 'internal conflict' as regressand, Robust regression, Ordered-Probit regression and Quantile regression are estimated.

Estimating alternative and competing model by taking alternative proxies of regressand, and estimating regression using closely relevant methods is termed as 'within method triangulation', in research. OrderedProbit, Ordered-Logistic and Quantile regression models have been preferred keeping in view semi-parametric or the ordinal arrangement both the regressands, while Prais-Winsten and Robust regression models are preferred for caution of heteroscedasticity and serial correlation in the time series data. While specifying alternative econometric models we have refrained from overstretching and avoid taking several variables into a single model: instead, several competing models have been estimated taking alternative regressors into competing models. 
Table 1. Robust Regression, Ordered Logistic, Prais-Winsten, Ordered-probit, and Quantile Regression estimates for alternative regressands

\begin{tabular}{|c|c|c|c|c|c|c|}
\hline \multirow[b]{2}{*}{ Regressors } & \multicolumn{3}{|c|}{$\begin{array}{l}\text { Regressand: Civil War (Scale 0- 4: } 0 \text { being high } \\
\text { risk of Civil War, while } 4 \text { imply no risk) }\end{array}$} & \multicolumn{3}{|c|}{$\begin{array}{l}\text { Regressand: Internal Conflict (Scale 0-12: } 0 \\
\text { being high risk, } 12 \text { imply no conflict). }\end{array}$} \\
\hline & $\begin{array}{c}\text { Robust } \\
\text { Regression }\end{array}$ & $\begin{array}{l}\text { Ordered } \\
\text { logistic } \\
\text { Model }\end{array}$ & $\begin{array}{c}\text { Prais- } \\
\text { Winsten } \\
\text { Regression }\end{array}$ & $\begin{array}{c}\text { Robust } \\
\text { Regression }\end{array}$ & $\begin{array}{l}\text { Ordered } \\
\text { probit } \\
\text { Model }\end{array}$ & $\begin{array}{l}\text { Quantile } \\
\text { Regression }\end{array}$ \\
\hline Rate of Unemployment. (IMF Data) & ------ & ------- & ------ & $\begin{array}{c}.2753919 * * * * \\
(-2.88)\end{array}$ & ------- & ------- \\
\hline $\begin{array}{l}\text { Litigation against State Institutions. (Petitions } \\
\text { against State Institutions at Federal } \\
\text { Ombudsman). }\end{array}$ & $\begin{array}{l}-.0000367 * * * \\
(-6.22)\end{array}$ & $\begin{array}{c}-.0002486^{* * * *} \\
(-4.34)\end{array}$ & $\begin{array}{l}-.0000247 * * * \\
(-6.67)\end{array}$ & ------ & $\begin{array}{c}-.000039 * * \\
(-2.13)\end{array}$ & $\begin{array}{c}-.000015^{*} \\
(-2.00)\end{array}$ \\
\hline $\begin{array}{l}\text { External Conflict. (Scale: 0-12: } 0 \text { for extreme } \\
\text { international pressures, while } 12 \text { for no } \\
\text { intervention). }\end{array}$ & $\begin{array}{c}.1304869 * * \\
(2.30)\end{array}$ & $\begin{array}{l}1.02758 * * * \\
(2.77)\end{array}$ & $\begin{array}{l}.2020106^{* * * *} \\
(5.02)\end{array}$ & $\begin{array}{l}.6524565^{* * * *} \\
(6.60)\end{array}$ & $\begin{array}{l}1.267482^{* * * *} \\
(4.87)\end{array}$ & $\begin{array}{l}.3777192 * * * \\
(4.61)\end{array}$ \\
\hline $\begin{array}{l}\text { Military in Politics. (Scale 0-6: } 0 \text { for } \\
\text { significant intervention, while } 6 \text { for no } \\
\text { intervention). }\end{array}$ & $\begin{array}{l}.6227386^{* * * *} \\
(3.16)\end{array}$ & $\begin{array}{l}4.237105^{* * * *} \\
(2.95)\end{array}$ & ------ & ------ & ------ & ------ \\
\hline $\begin{array}{l}\text { Ethnic Tensions. (Scale 0-6: } 0 \text { for High } \\
\text { Tensions, while } 6 \text { for Low Tensions). }\end{array}$ & $\begin{array}{l}.4678263^{* * * *} \\
(10.54)\end{array}$ & $\begin{array}{l}3.106321^{* * * *} \\
(4.26)\end{array}$ & $\begin{array}{c}.4053032 * * * \\
(8.45)\end{array}$ & $\begin{array}{l}.8184722 * * * \\
(11.30)\end{array}$ & $\begin{array}{l}1.627422 * * * * \\
(3.88)\end{array}$ & $\begin{array}{c}.7447918 * * * \\
(10.08)\end{array}$ \\
\hline $\begin{array}{l}\text { Dummy for Low/ High Geopolitics of } \\
\text { International Relations: (1: high significance, } \\
0 \text { neutral). }\end{array}$ & $\begin{array}{l}-.5988965^{* * * *} \\
(-3.55)\end{array}$ & $\begin{array}{c}-4.146342 * * * \\
(-3.15)\end{array}$ & ------ & ---- & $\begin{array}{l}-1.523856^{* *} \\
(-2.02)\end{array}$ & ------ \\
\hline $\begin{array}{l}\text { Interaction of 'Dummy for Geopolitics of } \\
\text { International Relations' with 'Ethnic } \\
\text { Tensions'. }\end{array}$ & ------ & ------ & $\begin{array}{c}-.199064 * * * \\
(-4.85)\end{array}$ & $\begin{array}{l}-.3367789 * * * \\
(-3.54)\end{array}$ & ----- & $\begin{array}{c}-.4186386 * * * \\
(-4.72)\end{array}$ \\
\hline $\begin{array}{l}\text { Democratic Accountability. (Scale } 0-6 \text { : } 0 \text { for } \\
\text { no accountability, while } 6 \text { for highly } \\
\text { accountable). }\end{array}$ & ------ & ------ & ------ & $\begin{array}{c}-.2095243 * \\
(-1.76)\end{array}$ & - & ------ \\
\hline $\begin{array}{l}\text { Religious Tensions. (Scale.0-6: } 0 \text { for High } \\
\text { Tensions, while } 6 \text { for Low Tensions). }\end{array}$ & - n- & - & - & - & $\begin{array}{c}3.605302^{* * * *} \\
(3.25)\end{array}$ & $\begin{array}{c}1.044649 * * \\
(0.026)\end{array}$ \\
\hline $\begin{array}{l}\text { Government Stability. (Scale 0-12: } 0 \text { for } \\
\text { instability, while } 12 \text { for highly stable). }\end{array}$ & $\begin{array}{ll}-1 \\
----\end{array}$ & $\begin{array}{ll}-1 \\
----\end{array}$ & $\begin{array}{c}.0843188^{* *} \\
(2.43)\end{array}$ & - & ----- & ----- \\
\hline Constant & 1.545158 & ----- & .464085 & 1.838522 & ----- & 1.67952 \\
\hline $\mathrm{N}$ (Years) & 33 & 33 & 33 & 33 & 33 & 33 \\
\hline \multicolumn{7}{|l|}{ Estimates and tests of Goodness of Fit } \\
\hline $\mathrm{R}^{2}$ & ------ & ------ & 0.90 & ------ & ------ & ------ \\
\hline Adjusted $\mathrm{R}^{2}$ & ------ & ------ & 0.88 & ------ & ------ & ------ \\
\hline F Ratio $(5,27)$ & 52.25 & ------ & 48.60 & 44.92 & ------ & ------ \\
\hline Pseudo $\mathrm{R}^{2}$ & ------ & 0.48 & ------ & ------ & 0.42 & 0.71 \\
\hline Likelihood-ratio & ------ & -38.83 & ------ & ------ & -53.97 & ------- \\
\hline $\mathrm{LR}\left(\mathrm{Chi}^{2}\right)$ & ------- & 73.92 & ------- & ------- & 78.46 & ------- \\
\hline
\end{tabular}

Source: Own elaboration.

Note: Below the coefficient in ( ) parentheses Z/t values are reported.

Significance of Regression co-efficients is projected at $10 \%, 5 \%$ and $1 \%$ levels of significance using $*, * * * *$ notations along with regression co-efficients, respectively.

Estimates of all six competing models: three by taking rating of 'Civil War' as regressand; while three models by taking the 'Internal Conflict' rating as regressand are given in Table1, above. Overall goodness of fit estimates as well as tests of goodness of fit of all estimated models showed either high or moderate to high explanatory power. Taking Civil War rating as the dependent variable three models have been estimated: Robust Regression F-ratio (5, $27 \mathrm{df}$ ) appears to be at 52.25; Ordered Logistic regression yields Pseudo $\mathrm{R}^{2}$ at 0.48 with $\mathrm{LR}\left(\mathrm{Chi}^{2}\right)$ at 73.92 ; while Prais-Winsten Regression estimates of Adjusted $\mathrm{R}^{2}$ appeared to be at 0.88 with F-ratio $(5,27 \mathrm{df})$ estimate at 48.60. Similarly, regression models taking 'Internal Conflict' rating as the dependent variable showed respectable estimates: Robust Regression F- ratio (5, 27 df) appears to be 44.92; Ordered Probit regression yields Pseudo $\mathrm{R}^{2}$ at 0.42 with $\mathrm{LR}\left(\mathrm{Chi}^{2}\right)$ at 78.46 ; while Quantile Regression estimates of Pseudo $\mathrm{R}^{2}$ appeared to be 0.71 .

High overall significance of estimated models with high significance of regression co-efficients entails that models have not adversely been affected due to apprehensions of high multicollinearity. Multicollinearity in the time series data is not just seen when we have typically quantitative data, but may also be reflected when 
semi-parametric data in form of ratings, tends to move in same direction, overtime. In estimated models above, we have tried to use a mix of the quantitative variables, data on ratings, intercept dummy as well as the interaction/ slope dummy, to avoid any apprehension or suspicion of high multicollinearity.

Estimates of competing models suggests that the core hypothesis, aiming at testing significance of geopolitics of international relations in relation to 'civil war'/ 'internal conflict', appeared significant in all 3 models, either at $1 \%$ or at $5 \%$ level of significance. We can infer that in periods of High Geopolitical Significance, both 'civil war' and 'Internal conflict' ratings affected adversely and significantly. Interaction dummy of 'Geopolitics of International relations' with 'ethnic tensions', was included in 3 models to test if the interplay of 'Geopolitics of International Relations' and 'Ethnic tensions' jointly alter 'Civil War'/ 'Internal Conflict', implied high significance at $1 \%$ level of significance in all 3 estimated models.

Effect of 'External Conflict' in impacting 'Internal Conflict' has been tested in 5 estimated models, showing direct and significant impact of 'External Conflict' as an incremental factor causing adversity in 'Internal conflict'. External conflict, either appearing in form sanction/ termination of Aid inflows, foreign pressures to collaborate with international players or in form of border tensions not just creep uncertainty but a situation where stakeholders remain uncertain where to bind their loyalties. Proxy wars, infiltrations and growing tendencies of insurgencies in Baluchistan etc. are typical cases of external factors causing domestic problems regarding law and order. Significance of 'Ethnic tensions' in affecting 'Internal Conflict'/ 'Civil War', was tested in all 6 models and estimates show that it has a sizable and statistically significant impact of 'Ethnic tensions' upon 'Internal Conflict'/ 'Civil War', even at 1\% level of significance. Segregation, divide, gaps and differentiated preferences of state in dealing with different ethnic groups are readily available basis of polarization, which may lead to either insecurity or misintegration of society and the state. Similarly, the role of military was tested in two models and appeared significant even at $1 \%$ level of significance: implying role of military in politics and also in launching military operations, without the consent of the political regime has had incremental role in worsening conflict like circumstances. In last couple of years we have witnessed strong resentment against military operations in Swat, Bajour and in Waziristan agency, not by the general public but in the form of Pashtun Tahafuz Movement (PTM) which emphasizes that ruthless military operations, extra judicial killings and unconstitutional detention centers have added vulnerabilities of people who suffered from terrorism in past and now are being suffering from state repression.

Institutional inefficacies as estimated in form of petitions/ complaints against state institutions at federal ombudsman reveal that institutional inefficacies or the weak legitimacy of the state contributes to conflict like situation, significantly. In estimate of Robust regression, it is out of the ordinary to observe that attempts of democratic accountability and its frequency have had adverse impact upon conflict, perhaps due to the reason that most attempts of accountability of politicians eventually appeared counterfeit in the court of law, were vindicated in nature and a form of political victimization. Tendency and propensity of self assessment, self appraisal and making claims of high self esteem by the top hierarchy of judiciary in capacity of dispute settlement mechanism time to time rather continually with bleak ranking and rating by the World Justice Project is a matter of grief, necessitate attention of academicians and feed back by civil society. For instance, Saqib Nisar the ex chief justice of Pakistan while presenting the case for judiciary claimed that "significant rise in petition and cases being filed in the Supreme Court of Pakistan shows faith of the general public on Supreme Court of Pakistan". Reversal and suspension of lower court verdict as they proceed from lower to higher hierarchy for example from civil court to session court , from session court to high courts and from high courts to the supreme court create strong allusion among stake holders to continually investing on prominent lawyers and to run after court verdicts in own favor. It denies the foremost principle of access to justice; convicted persons may be freed if he/she chooses to follow up, while people who could not afford may bear high opportunity cost in terms of loss of right or in form of punishment. Negating verdicts of lower courts by the higher judiciary either imply incompetence of lower courts or the snob effect of higher judiciary to exert supremacy through refutation. Several chief justices of Supreme Courts of Pakistan especially in the last decade while speaking in public seminars and through observations during court proceedings praised judiciary with regards to efficacy, impartiality and free from corruption. Trying to inscribe or dictate own history instead of waiting for historian to write on it or to hear public voices has a long history in the subcontinent. Government ministers, government officials and politicians especially in last two political regimes in Pakistan faced over generalized comments, derogatory remarks in court proceedings, humiliation and punishment even under the clause of contempt of court by the top judiciary. Side by side the Sou Moto Law 
was being practiced extensively against sitting governments causing violation of the right of appeal as well as impression of awful reputation on part of politicians. The present regime of Pakistan Tehreek-e-Insaf (PTI), which is being suspected of being back by of establishment is provided with a comparative lead by the judiciary as hearing on civil and criminal cases against PTI politicians have been deferred, the practice of Suo motu law remained silent, while the National Accountability Bureau primarily focusing upon opposition political parties. Theories of prejudice suggest that despite apparent bias, favoritism of one stake holder creeps bias and the phenomenon of hatred by others. Historically speaking, top political leaders in Pakistan were executed, murdered, convicted or imprisoned even without presenting any challan. High rates for political imprisonment with low efficacy of judicial system stimulate vulnerabilities and fragility of politicians, implying distrust on political parties by the masses and creeps likelihood of military intervention.

Based upon results of estimated models reflecting sensitivity of external conflict, geopolitics of international relations and strong connectivity of geopolitics of international relations with ethnic tensions, it may be inferred that state of Pakistan need to fabricate sovereign stance, especially while extending support to international players in a conflict like situation. It is urged that ethnic and religious polarization to be dealt through political mainstreaming and reforms; the role of military to be confined to border surveillance to curb proxy wars; while, factors like border tensions and external conflict to be resolved through dialogue and diplomacy, amicably.

\section{Conclusion and need for further research}

In order to avoid conflict within state of Pakistan, careful attention needs to be paid in instances that require collaboration or assistance of Pakistan in international disputes, especially when instead of mediation its offensive role is defined by international players. Long term consequences of such collaborations need to be recognized not only by the political leadership but also by the establishment, to avoid direct damages as well as induced vulnerabilities of participation in such international disputes. External conflicts such as border tensions with neighboring countries require effective diplomacy and amicable resolution of pending issues. Since India and Pakistan, both sustain the status of nuclear states, apprehensions of proxy wars in form of infiltration, sponsoring and providing ammunition to rebel groups inside Pakistan have increased over time. There is a need to improve surveillance and intelligence services on borders. Remote and deprived areas of Pakistan who received sizable damages during the Afghan war and then in the war against terrorism requires developmental initiatives, along with attempts to streamline deprived or marginalized segments of society, as part of the political system.

History of modern civilization has witnessed numerous instances of interventions: how international players maneuver willing followers, exert pressures through sanctions and border disputes; supplement their motives through ethnic polarization by supporting rebel groups; and leading a country to irreparable losses in terms of human tragedy, loss of livelihood and a bleak future. It is always been important for coalition partners to carefully investigate the doubt or the suspicion that originates such lethal preemptions: International Atomic Energy Agency (IAEA) report by Al Bradi on Iraq that led to preemptive strikes and mass destruction in Iraq, eventually appeared fake; while US-Iran nuclear deal has recently been suspended, creeping doubts of preemptive strikes against Iran.

We feel that instead of doing panel data studies of several countries that are prone to risk and insecurity, time series analysis of individual countries may yield somewhat better understanding in identification of predominant factors that led to a conflict like situation. Most of panel data studies have generic findings for a group of countries but can't be authenticated in a specific country as different countries may have different orientation or composition of geopolitics so incorporating several countries into a single study cause overgeneralization and problems that are associated with degrees of freedom.

\section{Acknowledgments}

Authors greatly admire contribution by Mobina Qayyum, Syed Naveed Akhter, Kristen Nordhaug, Nadeem Syed and by Faiza Nadeem for their persistent support and valuable suggestions concerning substance and construction of the study. 


\section{References}

1. Adams, K., Evangelides, A., Gray, E., Gryskiewicz, A., Patiño, C., Harman, M., Hopkins, A., Ibrahim, A., Chamness, S., Martin, R., Morales, J., Ponce, A., Pratt, C., Saravia, L., Silvas, R., Stephan, A., and The World Justice Project. (2019). Rule of law index. (Various editions). Washington, D.C: World Justice Project.

2. Ali, M. (2009). US Foreign aid to Pakistan and Democracy: An overview. Pakistan Journal of Social 29(2), $\mathrm{pp}$ 247-258. http://citeseerx.ist.psu.edu/viewdoc/download?doi=10.1.1.717.8056\&rep=rep1\&type=pdf.

3. Anderson, J. (2004). American Hegemony after 11 September: Allies, Rivals and Contradictions. Brunn, Stanley, D. (edt). 11 September and its aftermath: the Geopolitics of terror, 33-59. DOI: 10.1080/14650040412331307702.

4. Braithwaite, J. \& D'Costa, B. (2018). Cascades of Violence: War, Crime and Peace building Across South Asia, ANU Press, The Australian National University. https://press.anu.edu.au/publications/series/peacebuilding-compared/cascades-violence.

5. Cederman, L., Kristian, G., and Halvard B. (2013). Inequalities, Grievances, and War. Cambridge University Press. DOI: 10.1017/CBO9781139084161.

6. Chenoweth, E. \& Maria J. S. (2012). Why Civil Resistance Works: The Strategic Logic of Nonviolent Conflict, Columbia University Press. DOI: 10.1162/isec.2008.33.1.7

7. Collier, P. \& Hoeffler, A. (2004). Greed and Grievance in Civil War. Oxford Economic Papers, 56, 563-595. DOI: 10.1093/oep/DOI: 10.1093/oep/gpf064

8. Dalby, S. (2004). Calling 9/11: Geopolitics, Security and America's New War. Stanley, D. Brunn (edit). 11 September and its aftermath: the Geopolitics of terror. Frank Cass Publishers , London, 60-84. DOI: 10.1080/14650040412331307712

9. Dudlák T. (2018). After the sanctions: Policy challenges in transition to a new political economy of the Iranian oil and gas sectors, Energy Policy, 121, 464-475. DOI: 10.1016/j.enpol.2018.06.034.

10. Fearon, J. \& David, L. (2003). Ethnicity, Insurgency and Civil War. American Political Science Review, 97(1), 75-90. DOI: 10.1017/S0003055403000534.

11. Fearon, J. D. (1995). Rationalist Explanations for War. International Organization, 49(03), 379-414. DOI: 10.1017/S0020818300033324

12. Fielden, M. B. (1998). The geopolitics of aid: the provision and termination of aid to Afghan refugees in North West Frontier Province, Pakistan, Political Geography, 17(4), pp 459-487. DOI: 10.1016/S09626298(97)00034-6

13. Fleck, K., \& Kilby, C. (2009).Changing aid regimes? US foreign aid from the cold war to the War against Terrorism. Journal of Development Economics, 91, 185-197. DOI: 10.1016/j.jdeveco.2009.09.011

14. Flint, C. (2017). Introduction to Geopolitics. Routledge, New York, NY. ISBN: 9781138192157

15. Fund for Peace (2018). Fragile State Index: Methodology and Cast Framework. https://fragilestatesindex.org/2017/05/13/fragile-states-index-and-cast-framework-methodology/.

16. Geller, D. S. (2003). Nuclear Weapons and the Indo-Pakistani Conflict: Global Implications of a Regional Power Cycle. International Political Science Review, 24(1), 137-150. DOI: $10.1177 / 0192512103024001009$.

17. Gleditsch, Kristian \& Ruggeri, Andrea (2010). Political Opportunity Structures, Democracy and Civil War. Journal of Peace Research, 47(3), 299-310. DOI: 10.1177/0022343310362293

18. Government of Pakistan (2010). Cost of War on Terror for Pakistan Economy. Economic Survey of Pakistan, Published by the Government of Pakistan. http://www.finance.gov.pk/survey/chapter_11/Special\%20Section_1.pdf

19. Hegre, Håvard; Ellingsen,Tanja, Gates,Scott, \& Nils Petter Gleditsch (2001). Toward a Democratic Civil Peace? American Political Science Review, 95(1), pp 33-48. DOI: 10.1017/S0003055401000119

20. Humphreys, Macartan \&Jeremy Weingast. (2008). Who Fights? The Determinants of Participation in Civil War. American Journal of Political Science, 52(2), 436-455. DOI: 10.1111/j.15405907.2008.00322.x

21. Kalyvas, S. N. \& Balcells, L. (2010). International System and Technologies of Rebellion: How the End of the Cold War Shaped Internal Conflict. American Political Science Review, 104(03), 415-429. E-ISSN: $\underline{15375943}$ 
22. Makeig, D. C. (1987). War, No-War, and the India-Pakistan Negotiating Process. Pacific Affairs, 60(02), 271-294. DOI: $10.2307 / 2758135$

23. Meernik, J., Krueger, E. L. \& Poe, S. C. (1998). Testing models of US foreign policy: Foreign aid during and after the cold war. The Journal of Politics, 60(1), pp 63-85. DOI: 10.2307/2648001

24. Modelski, G. (1987). Long Cycles of World Politics. Seattle: University of Washington Press. DOI: http://dx.doi.org/10.1086/ahr/95.2.456

25. Nasir, M., Rehman, F. U., Orakzai, M. (2012). Exploring the nexus: Foreign aid, war on terror, and conflict in Pakistan. Economic Modelling, 29(4), 1137-1145. DOI: 10.1016/j.econmod.2012.04.004.

26. Ollapally, D. M. (2008). The Politics of Extremism in South Asia. Cambridge University Press, New York pp. 66-102. DOI: 10.1080/09546553.2013.842401

27. Pakistan Bureau of Statistics (2019). Pakistan Statistical Yearbook (various editions). Published by the Government of Pakistan. http://www.pbs.gov.pk/

28. Political Risk Services Group (2017). International Country Risk Guide, Published by the Political Risk Services Group. https://www.prsgroup.com/explore-our-products/international-country-risk-guide/

29. Quy-Toan Do, Jacob N. Shapiro, Christopher D. Elvidge, Mohamed Abdel-Jelil, Daniel P. Ahn, Kimberly Baugh, Jamie Hansen-Lewis, Mikhail Zhizhin, Morgan D. Bazilian, (2018). Terrorism, Geopolitics, and oil security: Using remote sensing to estimate oil production of the Islamic State, Energy Research \& Social Science, 44, 411-418. DOI: 10.1016/j.erss.2018.03.013

30. Reuber, P. (2009). Geopolitics. International Encyclopedia of Human Geography, pp. 441-452. https://doi.org/10.1002/9781118786352.wbieg0738

31. Transparency International (2018). Corruption Perception Index, annual reports (1995 to 2018). Transparency International, International Secretariat Alt-Moabit 9610559 Berlin Germany. https://www.transparency.org/files/content/pages/2018_CPI_Executive_Summary.pdf

32. Uprety, K. \& Salman, S. M. A. (2011). Legal aspects of sharing and management of trans-boundary waters in South Asia: preventing conflicts and promoting cooperation. Hydrological Sciences Journal, 56(4), 641-661. DOI: https://doi.org/10.1080/02626667.2011.576252

33. Wallace, R. D. (2014). North Korea and diversion: A quantitative analysis (1997-2011), Communist and Post-Communist Studies, 47(2), 147-158. DOI: 10.1016/j.postcomstud.2014.04.004

34. Wolf, A.T., Kramer, A., Carius, A., \& Dabelko, G. D. (2005). Managing Water Conflict and Cooperation, State of the World: Redefining Global Security. State of the World: Redefining Global Security, World Watch Institute, pp 80-95. https://www.academia.edu/9726127/Managing Water Conflict and Cooperation 